\title{
Synthesis and Regulation of Bacillus circulans WL-12 1,3- $\beta$-D-Glucanases
}

\author{
By ROSA ESTEBAN, ' ANGEL R. NEBREDA * AND \\ TOMAS G. VILLA? \\ 'Department of Microbiology, Faculty of Biology, Unitersity of Salamanca, Spain \\ 'Department of Microbiology: Faculty of Pharmacy, Unicersity of Santiago, Spain
}

(Received 16 April 1984: revised 31 May 1984)

\begin{abstract}
Bacillus circulans WL-12 1,3- $\beta$-D-glucanases are extracellular enzymes subject to catabolite repression by glucose and synthesized after the depletion of this sugar. Utilization of other complex carbon sources (1,3- $\beta$-D-glucan from baker's yeast, laminarin or xylan) resulted in a 3to 4-fold increase in the formation of these enzymes, suggesting that they are derepressible and inducible. Under induction conditions four different enzymes were detected by isoelectric focusing that were numbered I, II, III and IV, according to their isoelectric points $(3 \cdot 7,4 \cdot 6,5 \cdot 5$ and 6.5 respectively). Glucanase II was inducible whereas I, III and IV were both derepressible and inducible. In addition, the synthesis of glucanase II was blocked by cyclic AMP. The four enzyme forms displayed an endo- attack on laminarin and yielded similar products, but differed in some physico-chemical parameters such as molecular weight, $K_{m}$ and lytic activity.
\end{abstract}

\section{INTRODUCTION}

Bacillus circulans WL-12 was isolated by Tanaka \& Phaff (1965) from soil samples and characterized by its ability to lyse a number of fungal and yeast cell walls. When the microorganism was grown with complex carbon sources, the supernatant broths contained a variety of hydrolytic enzymes such as 1.3- $\beta$-D-glucanase (Kobayashi et al., 1974: Tanaka et al., 1974, 1978, 1981: Fleet \& Phaff, 1974: Rombouts \& Phaff, 1976 b), 1,6- $\beta$-D-glucanase (Rombouts \& Phaff, 1976a: Johnson et al., 1979), 1,3- $\alpha$-D-glucanase (Johnson et al., 1979; Meyer \& Phaff, 1980), chitinase (Johnson et $a l ., 1979$ ) and $\beta$-xylanase (Esteban et al., 1982).

Tanaka et al. (1974) proposed the term 'concerted induction' to explain the formation of different forms of 1.3- $\beta$-D-glucanase when the micro-organism was grown with fungal cell walls as the carbon source. Fleet \& Phaff (1974) and Johnson et al. (1979) considered that both the 1,3$\beta$-D- and 1,6- $\beta$-D-glucanases were strictly inducible. In the present work we describe the induction and derepression of these enzymes (mainly 1,3- $\beta$-D-glucanases), different forms of which are present in culture supernatants depending on the carbon source used and also on the presence of exogenous cyclic AMP. We also summarize the main physico-chemical properties of glucanases I, II, III and IV (separated by isoelectric focusing) and discuss their homology with the forms identified in previous papers (Fleet \& Phaff, 1974; Rombouts \& Phaff, 1976 b).

\section{METHODS}

Micro-organism and culure comditions. Bucillus circulums WL-12 was maintained and cultured as previously described (Fsteban et al. 1982). The growth medium contained yeast nitrogen base $\left(0.7^{\circ}{ }_{0}\right.$; Difco), and carbon sources (glucose. 1.3- $\beta$-D-glucan from baker's yeast and $\beta$-xylan) at a final concentration of $0 \cdot 5^{\circ}$. Occasionally. glucose was used at $2^{\circ}{ }_{0}(w \mathrm{v})$. The bacterium was grown aerobically $(300 \mathrm{ml}: 1000 \mathrm{ml}$ flasks) from an inoculum of $10^{\prime \prime}$ cells $\mathrm{ml}{ }^{\prime}\left(3 \mathrm{ml}: 10^{\circ}\right.$ cells $\mathrm{ml} '$ final concentration) at 30 'C in a rotary shaker at $250 \mathrm{r} . \mathrm{p} . \mathrm{m}$. for $3 \mathrm{~d}$. Glucose utilization was monitored by estimating unused glucose by the modification of Bruss \& Black (1978) of Keston's method (1956).

Preparation of en:lyme sample's. Simples of culture were withdrawn (every $3 \mathrm{~h}$ and up to $68 \mathrm{~h}$ ) and bacterial cells collected by centrifugation at $2000 \mathrm{~g}$ for $10 \mathrm{~min}$. The supernatants were dialysed for $24 \mathrm{~h}$ at 4 " $\mathrm{C}$ against twice- 
distilled water and total 1,3- $\beta$-D- and 1,6- $\beta$-D-glucanases determined. When higher enzyme activity per unit volume was needed, the dialysates were concentrated by ultrafiltration through Amicon PM-10 membranes. The volume of the samples could be reduced about 20-fold by this procedure with no apparent loss of enzyme activity.

Enzyme assays. 1,3- $\beta$-D- and 1,6- $\beta$-D-glucanases were assayed with laminarin and pustulan (prepared in 0.1 $\mathrm{M}$ sodium acetate buffer, pH 5.2; 0.5\% final concentration) as substrates, respectively. To $0.1 \mathrm{ml}$ enzyme solution. $0.1 \mathrm{ml}$ substrate was added and the mixture incubated at $30^{\circ} \mathrm{C}$ for appropriate periods of time. The reducing power released from the substrates was determined (Somogyi, 1952; Ashwell, 1957), using glucose as the standard. One enzyme unit was defined as the amount of enzyme that catalysed the release from the substrate of I nmol glucose, or equivalent reducing power, per min at $30^{\circ} \mathrm{C}$. Specific activity was determined by referring the number of enzyme units either to the number of bacterial cells or to mg protein as determined by the Lowry method with bovine serum albumin as the standard.

Isoelectric focusing. Fractionation of the $\beta$-glucanases in culture broths was accomplished in a $110 \mathrm{ml}$ LKB isoelectric focusing column. The density gradient was formed with glycerol, and ampholite (pH 4-6.5) was used at a concentration of $1 \%(w / v)$. The rest of the procedure was as previously described (Esteban $e t$ al., 1982).

Paper chromatography. Paper chromatography was done on Whatman no. I paper with ethyl acetate/pyridine/water ( $8: 2: 1$, by vol.) as solvent. The spots were visualized according to the method of Trevelyan et al. (1950).

Gel exclusion chromatography. Molecular weight determinations were done in a column $(60 \times 0.6 \mathrm{~cm})$ packed with Biogel P-100, equilibrated with 0.1 M-sodium acetate buffer (pH 5-2) and calibrated with proteins of known molecular weights (bovine serum albumin, 67000; egg albumin, 43000; chymotrypsinogen A, 25000 and ribonuclease A, 13700). Fractions of $0.5 \mathrm{ml}$ were collected and the void volume of the column was determined by the elution of blue dextran 2000.

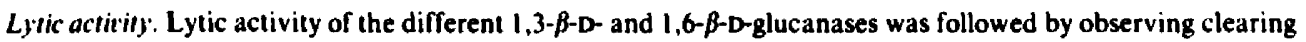
zones in agar plates containing suspended cell walls of Saccharomyces cererisiae. The method was similar to that described by Rombouts \& Phaff (1976a,b).

Chemicals. Xylan (from larch wood) and cyclic AMP were obtained from Sigma, purified xylan was prepared as described previously (Esteban et al, 1982) and alkali-insoluble 1,3- $\beta$-D-glucan from baker's yeast was prepared according to the procedure of Manners et al. (1973). Laminarin was purchased from Koch-Light Laboratories, and pustulan from Calbiochem-Behring Corp. Other chemicals were of the best quality available.

\section{RESULTS AND DISCUSSION}

\section{Effect of different carbon sources on the production of 1,3- $\beta$-D- and I,6- $\beta$-D-glucanases by} B. circulans $W L-12$

Previous authors have suggested (Fleet \& Phaff, 1974; Johnson et al., 1979), in an apparently unambiguous way, a strictly inducible nature for $B$. circulans WL-12 1,3- $\beta-D-$ and 1,6- $\beta$-Dglucanases. However, our results indicated that once glucose was depleted from the culture medium, the enzymes were synthesized; if glucose was not exhausted (i.e. growth in the presence of $2 \%$ glucose) they were not synthesized. It follows that 1,3- $\beta$-D- and 1,6- $\beta$-D-glucanases of $B$. circulans WL-12 are subject to catabolite repression and in this sense they may be considered as derepressible enzymes. Table 1 summarizes the total enzyme activities obtained by growing the bacterium with different carbon sources. With $0.5 \%$ glucose as the carbon source, the glucanase activities were about $30 \%$ of those obtained with 1,3- $\beta$-D-glucan. Xylan, even after purification (Esteban $e t$ al., 1982) gave enzyme activities greater than those obtained with glucose. It is therefore likely that $B$. circulans WL-12 $\beta$-glucanases are inducible, though it is not clear why the bacterium should synthesize $\beta$-glucanases when a xylan is used as the carbon source. One explanation could be that the expression of the respective genes is in some way coupled.

\section{Separation of $1.3-\beta$-D-glucanases by isoelectric focusing}

Tanaka et al. $(1974,1978,1981)$ have reported that $B$. circulans $W L-12$ is capable of producing different $\boldsymbol{\beta}$-glucanases, depending on the substrate used as the inducer. Because their studies used very complex carbon sources (whole cell walls isolated from a variety of fungi and yeasts), we thought that the use of simple substrates might shed some light on the problem of the variety of enzyme forms. Isoelectric focusing of samples from culture broths with $1,3-\beta$-D-glucan from baker's yeast and $\beta$-xylan as carbon sources resolved four 1,3- $\beta$-D-glucanases, which we numbered I (pI 3.7), II (pI 4.6), III (pl 5.5) and IV (pI 6.5), and only one 1,6- $\beta$-D-glucanase (pI 8.1) (Fig. $1 b, c)$. In the case of growth on $0.5 \%$ glucose, only three enzymes were detected, 
Table 1. I,3- $\beta$-D- and 1,6- $\beta$-D-glucanase activities present in the culture broths of B. circulans $W L-12$ grown with different carbon sources

The numbers represent percentages of activity as compared to those obtained with I,3- $\beta$-D-glucan as the carbon source $\left(100 \%\right.$ represents 180 units $\mathrm{ml}^{-1}$ for $1,3-\beta$-D-glucanases and 105 units $\mathrm{ml}^{-1}$ for $1,6-\beta$-D-glucanases). The samples were withdrawn after $65 \mathrm{~h}$ growth.

Growth substrate

1,3- $\beta$-D-Glucan
Pure xylan
Commercial xylant
Laminarin
Glucose $(0 \cdot 5 \%)$
Glucose $(2 \%)$

1,3- $\boldsymbol{\beta}$-D-Glucanase

100

59

66

50

27

0
1,6- $\beta$-D-Glucanase

100

60

74

53

33

- From baker's yeast.

+ Contaminated with callose.

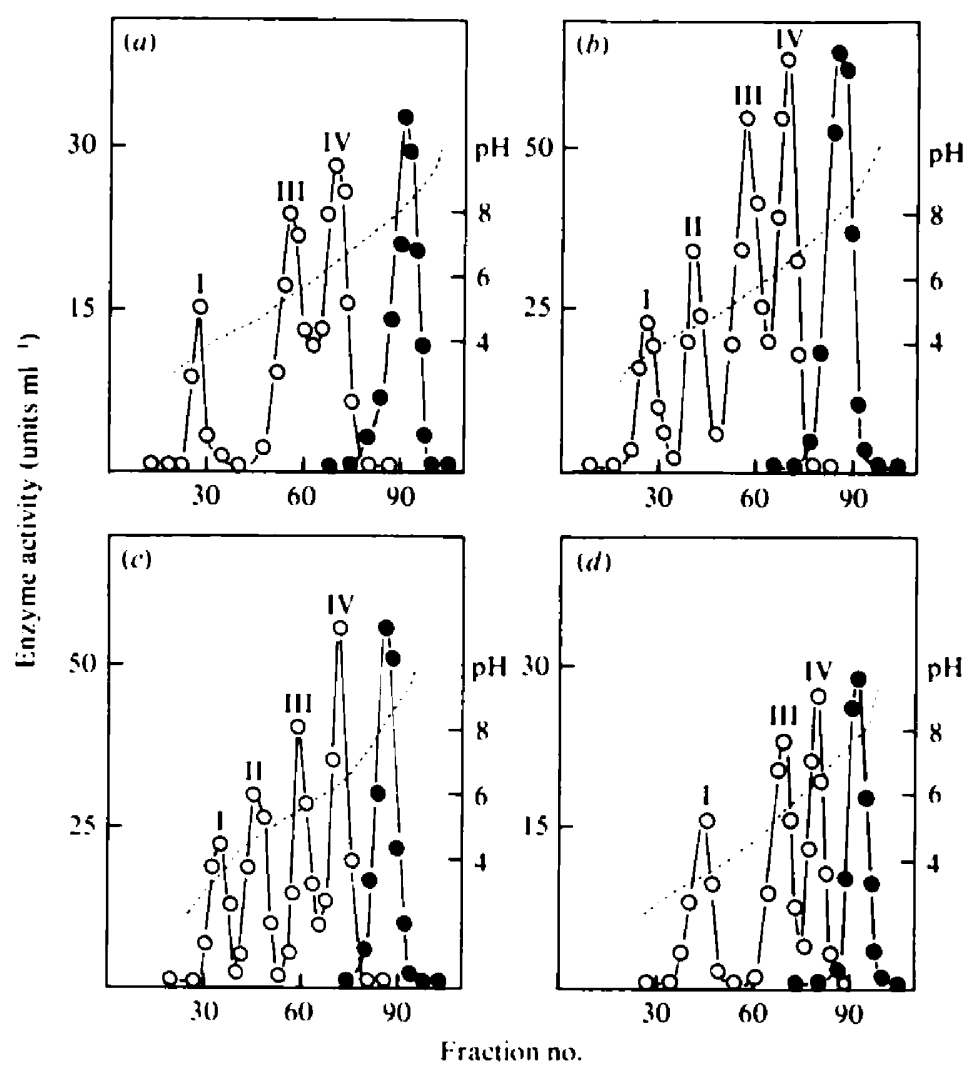

Fig. 1. Isoelectric focusing of supernatant broths of $B$. circulans WL-12 grown with $0.5^{\circ}$ glucose $(a)$. 1.3- $\beta$-D-glucan from baker's yeast $(h)$, purified xylan $(c)$ and $1,3-\beta$-D-glucan from baker's yeast supplemented with 8 mm-cyclic AMP (d). O. 1,3- $\beta$-D-Glucanase: O, 1.6- $\beta$-D-glucanase: , . pH.

corresponding to forms I. III and IV (Fig. la), indicating that form II seems to be the only one that is strictly inducible, whereas the other three forms are derepressible.

We have previously reported (Esteban et al., 1984) that cyclic AMP may control the synthesis of these enzymes as a negative effector. With this in mind we tried to find which of the enzyme forms was affected by the nucleotide when added exogenously $(8 \mathrm{mM})$ to a culture growing with 
Table 2. Percentages of the four forms of 1,3- $\beta$-D-glucanase obtained by growth of B. circulans WL-12 with different carbon sources

Data were calculated in each case from the results obtained by iscelectric focusing of the enzyme extracts (see Fig. 1) after collecting the gradient fractions which corresponded to the different isoelectric points.

$\begin{array}{ccc}\text { 1,3- } \beta \text {-D-Glucanase } & \overbrace{1,3-\beta \text {-D-Glucan }}^{\text {Growth substrate: }} \\ \text { I } & 17 & \text { Purified xylan } \\ \text { II } & 20 & 17 \\ \text { III } & 28 & 20 \\ \text { IV } & 35 & 24\end{array}$

Table 3. Comparison of the main physico-chemical properties of 1,3- $\beta$-D-glucanases secreted by B. circulans $W L-12$

\begin{tabular}{|c|c|c|c|c|}
\hline \multirow[b]{2}{*}{ Property } & \multicolumn{4}{|c|}{ 1,3- $\beta$-D-Glucanase : } \\
\hline & I & II & III & IV \\
\hline & $\begin{array}{l}\text { Derepressible } \\
\text { and inducible }\end{array}$ & Inducible & $\begin{array}{l}\text { Derepressible } \\
\text { and inducible }\end{array}$ & $\begin{array}{l}\text { Derepressible } \\
\text { and inducible }\end{array}$ \\
\hline & 27000 & 21000 & 35000 & 18000 \\
\hline & $3 \cdot 7$ & 4.6 & $5 \cdot 5$ & $6 \cdot 5$ \\
\hline $\left.\mathrm{mi}^{-1}\right) \dagger$ & $2 \cdot 0$ & $1 \cdot 23$ & 0.48 & $1 \cdot 12$ \\
\hline $\begin{array}{l}\text { olysis pattern } \neq \\
\text { activity§ }\end{array}$ & $\begin{array}{c}\text { Endo-acting } \\
-\end{array}$ & $\begin{array}{c}\text { Endo-acting } \\
+\end{array}$ & $\begin{array}{c}\text { Endo-acting } \\
+++\end{array}$ & $\begin{array}{c}\text { Endo-acting } \\
+\end{array}$ \\
\hline
\end{tabular}

- Determined by filtration through a Biogel P-100 column calibrated with proteins of known molecular weight.

+ The $K_{m}$ data correspond to values obtained by using the Hill representation. The different 1,3- $\beta$-D-glucanases were incubated with increasing amounts of the substrate (laminarin), and the results obtained were used for this representation.

$\ddagger$ Established by analysing hydrolysis products on paper chromatography (Whatman no. 1). Enzyme samples were incubated with the substrate (laminarin, $0.5 \%$ w/v) at $30{ }^{\circ} \mathrm{C}$. At time intervals, $20 \mu$ l samples of the mixtures were withdrawn and analysed by paper chromatography after heating the samples. Spots revealed mainly glucose, laminaribiose, laminaritriose and laminaritetraose, and minor quantities of larger oligosaccharides.

$\S$ Followed as described in Methods. - No lytic activity: + lytic activity, but without total clearing of the agar: +++ , total hydrolysis of the $S$. ceretisiae walls used in the assay.

1,3- $\beta$-D-glucan from baker's yeast as the carbon source. The results (Fig. $1 d$ ) revealed that form Il was missing, and that cyclic AMP was abolishing the stimulatory effect of the polysaccharide. This cyclic nucleotide did not alter the secretion of these enzymes, since cell-free extracts showed no particular enzyme accumulation.

From the results shown in Fig. 1, we calculated the percentage contribution of each $\beta$ glucanase to the total activity; the values are summarized in Table 2 . The four enzyme forms were synthesized in nearly the same proportion regardless of the polysaccharide used. As indicated above, the total $1,3-\beta$-D-glucanase activity with $0.5 \%$ glucose was about $30 \%$ of that obtained with a 1,3- $\beta$-D-glucan. If we assume that only $20 \%$ is strictly inducible (form II) it would appear that polysaccharides such as $1,3-\beta$-D-glucan from yeast and $\beta$-xylan in some way stimulate the synthesis of the remaining forms (I, III and IV).

The properties of the separated enzyme forms (Fig. 1) were studied in more detail (Table 3). Analysis of the lytic power ( 2 units of each enzyme form) revealed that enzyme I lacked this ability whereas the other three were each able to lyse $S$. cererisiae cell walls, $1,3-\beta$-D-glucanase III being the most active. Fleet \& Phaff (1974) also described the existence of a non-lytic $\beta$ glucanase that could be identified with our $1,3-\beta$-D-glucanase 1 , with the exception of the $K_{\mathrm{m}}$ value $\left(0.55 \mathrm{mg} \mathrm{ml}^{-1}\right.$ vs $2.0 \mathrm{mg} \mathrm{ml}^{-1}$. Table 3$)$. With respect to the lytic $1,3-\beta$-D-glucanases, Rombouts \& Phaff (1976 b) described two forms ( 1 and II). Their 1,3- $\beta$-D-glucanase l exhibited a higher lytic power and in this sense it could be identified with the 1,3- $\beta$-D-glucanase III 
described in this paper. Both have nearly the same molecular weight but again they differ somewhat in their $K_{m}$ values. Tanaka et al. (1974) reported a complex induction pattern for $B$. circulans WL-12 1,3- $\beta$-D-glucanases using Pyricularia oryzae mycelium and Tanaka et al. (1978) described the induction of four 1,3- $\beta$-D-glucanases, when the bacterium was grown on the yeast Debaryomyces hansenii, that exhibited isoelectric points similar to those reported here and therefore they may be identified with our forms I, II, III and IV. In view of all these results, it is difficult to understand how some of the complex carbon sources (e.g. Candida parapsilopsis walls) employed by Tanaka $e t$ al. (1978) induced only one form of 1,3- $\beta$-D-glucanase (pI 4-2). A possible explanation may be that such walls contain a compound that in some way prevented the formation of the other 1,3- $\beta$-D-glucanases.

Bacillus circulans WL-12 produced a single 1,6- $\beta$-D-glucanase (Fig. 1). Attempts were made, unsuccessfully, to resolve this fraction ( $\mathrm{pl} 8.1$ ) by different methods, including gel permeation chromatography (over Sephacryl S-200), DEAE-Biogel ion-exchange chromatography and ultracentrifugation in a sucrose gradient.

It may be concluded from the findings reported here that $B$. circulans $W L-12$ produced one 1,6- $\beta$-D-glucanase and up to four 1,3- $\beta$-D-glucanases, when grown with 1,3- $\beta$-D-glucan, xylan. laminarin or $0.5 \%$ glucose as carbon source. Of these latter enzymes, one was inducible (form II). whereas the remaining ones were derepressible and inducible.

\section{REFERENCES}

ASHWELL. G. (1957). Colorimetric analysis of sugars Methods in En:1mology 3, 73105.

Bruss, M. L. \& Black, A. L. (1978). Enzymatic microdetermination of glycogen. Analytical Biochemistr. 84, 309312

Esteban, R. Villanueva, J. R. \& Villa, T. G. (1982) $\beta$-D-Xylanases of Bacillus circulans WL-12. Canadian Journal of Microbiology 28. 733739

Estfaban. R. Nebreda, A. R.. Villanileva. J. R. \& Villa, T G. (1984). Possible role of c-AMP in the synthesis of $\beta$-glucanases and $\beta$-xylanases of Bacillus circulan. WL-12. FEMS Microhislog! Letters 23.91 94

Fleet, G. H. \& Phaff. H. J. (1974). Lysis of yeast cell walls: glucanases from Bacillus circulans WL-12 Journal of Bacteriology. 119, 207219

Johnson, E. A. Villa, T. G.. Lewis, M. J. \& Phaff, H. J. (1979). Lysis of the cell wall of the yeast Phaffia rhodozina by a lytic complex from Bacillus circulams WL-12. Journal of Applied Biochemistr. 1. 273 282.

Keston, A. S. (1956). Specific colorimetric enzymatic reagents for glucose. Abstracts of the 129 th Meeting of the American Chemical Society, p. $31 \mathrm{c}$

Kobayashi, Y., Tanaka, H. \& OGasawara. N. (1974). Multiple $\beta-1,3$-glucanases in the lytic complex of Bacillus circulans WL-12. Agricultural and Biological Chemistry 38, 959965.

manners, D. J.. Masson, A. J. \& Patterson. J. C (1973). The structure of a $\beta-(1 \rightarrow 3)$-D-glucian from yeast cell walls. Biochemical Journal 135, 1930

Merer. M. T. \& Phaff, H. J. (1980). Purification and properties of $(l \rightarrow 3+-\alpha$-glucanases from Bacillus circu- lans WL-12. Journal of General Microbiolog. 118. $197-208$.

Rombolts. F. M. \& Phaff. H. J. (1976a). Lysis of yeast cell walls. Lytic $\beta-(1 \rightarrow 6)$-glucanase from Bacillus circulans WL-12. European Journal of Biochemistry 63, 109120.

Rombot's, F. M. \& Phaff, H. J. (1976b). Lysis of yeast cell walls. Lytic $\beta-(1 \rightarrow 3)$-glucanases from Bacillus circulans WL-12. European Journal of Bioche'mistry 63, 121130 .

Somogy. M. (1952). Notes on sugar determination Journal of Biological Chemistry 195, 1923.

Tanaka, H. \& Phaff, H. J. (1965). Enzymatic hydrolysis of yeast cell walls. I. Isolation of walldecomposing organisms and separation and purification of lytic enzymes. Journal of Bacteriolog! 89. $1570-1580$.

TaNaka, H. Kobayashi, Y. \& Ogasawara, N. (1974). Concerted induction of the multiple $\beta$-1,3-glucanases in Bacillus circulans WL-12 in response to three different substrates. Agricultural and Biological Chemistry 38. 967972.

TANAKA, H. Itaklira. K. \& TODA, K. (1978). Concerted induction of $\beta$-glucanases of Bacillus circulans $W L-12$ in response to various yeast glucans. Agriculiural and Biological Chemistry 42, 16311636.

Tanaka, H., Kobayashi, Y., Itakura, K. \& KamiMIYA. S. (1981). Concerted induction of cell wall lytic enzymes in Bacillus circulans WL-12. Adrances in Biolectinology 4, 593598.

Trevelyan, W. E.. Procter, D. P. \& Harrison, J. S. (1950). Detection of sugars on paper chromatograms. Nature. London 116. 444445. 